\title{
A complicated wound
}

\author{
Teresa Brito, ${ }^{1}$ Inês Oliveira, ${ }^{1}$ Hugo Teles, ${ }^{1}$ Sara Carmo ${ }^{2}$
}

${ }^{1}$ Pediatrics Department, Hospital de São Bernardo, Setubal, Portugal

${ }^{2}$ Pediatric Surgery Department, Hospital de São Bernardo, Setubal, Portugal

Correspondence to

Dr Inês Oliveira,

inesfigueiredoliveira@gmail.com

Accepted 5 September 2019

\section{DESCRIPTION}

The patient is a 14-year-old male with a background of asthma, but otherwise healthy, with complete tetanus vaccination. Eight days before admission while playing football, he collided with another player and was bitten on the scalp. He was taken to his local urgent care centre where the $5 \mathrm{~cm}$ long scalp laceration on the right parietal region was sutured and he was discharged home.

Five days after the accident, due to spontaneous drainage of a great quantity of purulent content from the suture line, fever (maximum temperature $39^{\circ} \mathrm{C}$ ), drowsiness and asthenia, he went to his local accident and emergency department where the wound was cleaned and redressed and he was prescribed oral amoxicillin-clavulanate.

Despite being afebrile after 24 hours of antibiotic, as the purulent exudate discharge and local pain persisted, he was seen in our emergency room on day 8 of illness.

On examination, an abscess of the scalp with spontaneous drainage was evident. Blood tests showed haemoglobin of $15.7 \mathrm{~g} / \mathrm{dL}$, leucocytes of $11.8 \times 10^{6} \mathrm{uL}$ (neutrophils $62 \%$, lymphocytes $28 \%$ ), platelets of $324 \times 10^{6} \mathrm{uL}, \mathrm{C}$ reactive protein of $3.08 \mathrm{mg} / \mathrm{dL}$, glycaemia of $128 \mathrm{mg} / \mathrm{dL}$, normal ionogram and renal function. The patient was admitted into the paediatric ward for monitoring and intravenous antibiotic therapy with amoxicillin-clavulanate and metronidazole.

In day 4 of hospitalisation, the inflammatory signs of the suture line and purulent exudate were still present, the reason why a brain CT scan was performed in order to exclude the hypothesis of bone fracture and osteomyelitis. CT showed a bone density image on the right parietal region (figure 1). In three-dimensional reconstruction

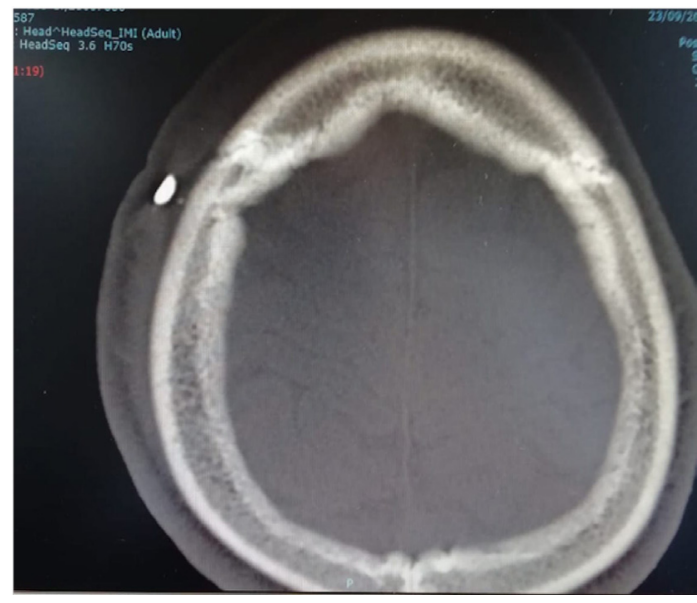

Figure 1 Brain CT scan showing a bone density image on the right parietal region.

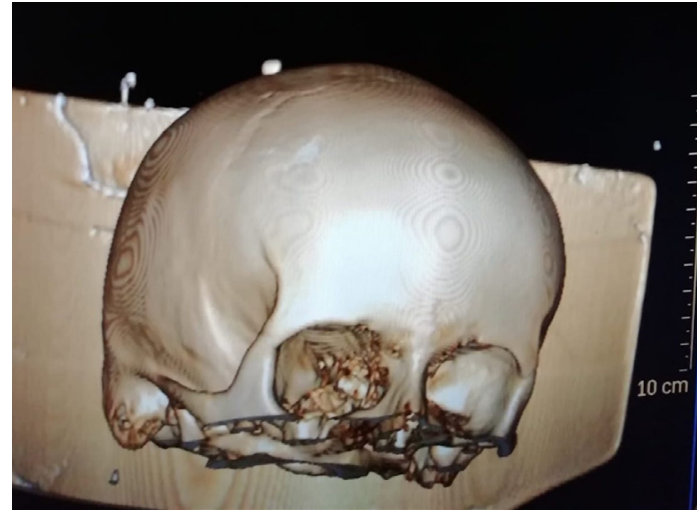

Figure 2 Three-dimensional reconstruction of the brain CT scan.

(figure 2), this image appears as a nodular image of calcium/metal density that could correspond to a tooth. The following day, the foreign body was extracted and confirmed to be a tooth. The procedure was uneventful and the patient was discharged after 48 hours, clinically well, having completing 7 days of intravenous antibiotics in a total of a 10-day course of antibiotics.

Head trauma is exceedingly common in children and frequently include scalp lacerations. ${ }^{1}$ Scalp infection after scalp laceration is a rare event, so it must raise awareness about its aetiology. ${ }^{1}$ Root cause of the wounds is typically identified while obtaining a history from the patient or the patient's family. When the mechanism of the wound is unknown or not clear, the evaluation and treatment of acute wounds typically does not change. The first step in traumatic wound management is irrigation, which both cleanses the wound and allows for thorough wound inspection. ${ }^{2}$

This case describes a very rare complication following a human bite injury. Nonetheless, it exemplifies how important it is to be aware of the risks associated to human or other animal bites, as they are frequent causes of extensively described complications (eg, osteomyelitis) when not properly managed. ${ }^{3}$

Palpable skull fractures are a criteria to obtain a head CT scan as the risk for clinically important traumatic brain injuries (ciTBIs) is up to $4.4 \%$, while scalp irregularities (eg, scalp haematoma or cephalohaematoma) are relevant only for children younger than 2 years of age. In this specific population, the risk of ciTBI in children with isolated scalp haematoma is $0.3 \%$. Skull fractures increase fourfold the risk of traumatic brain injuries (TBI on CT scan) which are different from ciTBI. ${ }^{45}$

CT scanning of the head remains the reference standard imaging study for patients with severe 


\section{Learning points}

Scalp infection after scalp laceration is a rare event, so it must raise awareness about its aetiology.

- Human bites, as well as foreign bodies, are associated with wound infections and other complications as osteomyelitis.

- In order to avoid complications, it is mandatory to maintain the procedure of suture reparation as sterile as possible.s

- Imaging may be indicated if there is a concern for an underlying fracture or a foreign body.

head trauma. ${ }^{6}$ Head CT scan may be a choice even for patients with minor head injuries if indicated by clinical prediction rules or when infection is suspected. ${ }^{5}$

For each patient, tetanus immunisation status should be checked and updated, especially when lacerations or contaminated wounds are present. ${ }^{7}$

Contributors TB: data acquisition, revision and approval of the manuscript. 10: data analysis, writing, revision and approval of the manuscript. HT: data analysis, revision and approval of the manuscript. SC: data acquisition and interpretation, revision and approval of the manuscript.

Funding The authors have not declared a specific grant for this research from any funding agency in the public, commercial or not-for-profit sectors.

Competing interests None declared.

Patient consent for publication Parental or guardian consent obtained.

Provenance and peer review Not commissioned; externally peer reviewed.

\section{REFERENCES}

1 Atabaki SM. Pediatric head injury. Pediatr Rev 2007;28:215-24.

2 Block L, King TW, Gosain A, et al. Debridement techniques in pediatric trauma and burn-related wounds. Adv Wound Care 2015;4:596-606.

3 Rothe K, Tsokos M, Handrick W. Animal and Human Bite Wounds. Dtsch Arztebl Int 2015:112:433-43.

4 Kuppermann N, Holmes JF, Dayan PS, et al. Identification of children at very low risk of clinically-important brain injuries after head trauma: a prospective cohort study. The Lancet 2009;374:1160-70.

5 Dayan PS, Holmes JF, Schutzman S, et al. Risk of traumatic brain injuries in children younger than 24 months with isolated scalp hematomas. Ann Emerg Med 2014;64:153-62.

6 Quayle KS, Powell EC, Mahajan P, et al. Epidemiology of blunt head trauma in children in U.S. emergency departments. N Engl J Med 2014;371:1945-7.

7 CDC. For Clinicians. https://www.cdc.gov/tetanus/clinicians.html.

Copyright 2019 BMJ Publishing Group. All rights reserved. For permission to reuse any of this content visit https://www.bmj.com/company/products-services/rights-and-licensing/permissions/

BMJ Case Report Fellows may re-use this article for personal use and teaching without any further permission.

Become a Fellow of BMJ Case Reports today and you can:

- Submit as many cases as you like

Enjoy fast sympathetic peer review and rapid publication of accepted articles

- Access all the published articles

- Re-use any of the published material for personal use and teaching without further permission

Customer Service

If you have any further queries about your subscription, please contact our customer services team on +44 (0) 2071111105 or via email at support@bmj.com.

Visit casereports.bmj.com for more articles like this and to become a Fellow 